\title{
Higher Education of Krasnodar Krai: Economic Aspects
}

\author{
Maria Vladimirovna Zelinskaya ${ }^{1}$ \\ Victoria Romeovna Mezhlumova1 \\ Antonina Leonidovna Boltava1 \\ Olga Yurievna Tarasova ${ }^{2}$ \\ Elena Yurievna Gadzheiva1 \\ ${ }^{1}$ Southern Managerial Institute \\ 2Kuban State Technological University \\ Email: Vika2207@mail.ru
}

Doi:10.5901/mjss.2015.v6n3s6p225

\begin{abstract}
The article considers economic aspects relating to the functioning of Krasnodar Krai higher education, analyzes the role of science in the educational process, the author describes the causes of educational sphere imperfection, considers the institutional division of science and education, and also scientific and educational areas integration. Thus, the main aim at the modern stage of education reforming must be a disclosure of potential of the scientific and educational processes interaction in the service organizations in the higher education sphere and justification of tools of these processes integration.
\end{abstract}

Keywords: science, education, public-private partnerships, economic aspects, scientific and educational areas integration.

\section{Introduction}

Education is the foundation of economics based on knowledge - economics of the post-industrial, information society. It trains specialists for concrete jobs and expands professional and common cultural horizons of the individual. Today it is the most important means and resource stimulating the achievement of creative personhood that makes the individual ready for life in the multicultural society, for making responsible decisions under conditions that give the freedom to choose, for the dialogue that is the form consciously accepted for cooperation and competition. The principle of "lifelong education" makes this kind of activity key for any person of our times - that makes the continuous modernization task of education the more important (The Civic chamber of the Russian Federation, 2007).

The mass media say that the structure and the content of the education system in Krasnodar Krai are determined both by all-Russian tendencies and regional peculiarities of Kuban. During the last 20 years the federal - regional education system is founded here and it helps to achieve goals of the continuous educational process effectively (Business Kuban, 2010).

We will allow to disagree with it because the education continuity task in Krasnodar Krai is solved basically by the formal presence of the consistent chain of educational institutions from preschool education to postgraduate and additional professional education, but it' $s$ to be noted that the consistency - the continuity on borders of various stages or education forms (the kindergarten - the school, the school - the higher education institution, the higher education institution - the postgraduate study, etc.), i.e. finally - the common organization of these stages or forms within the framework of the complete education system - is very important for creation of the real continuity of education.

In order to speak about the effectively operating common educational environment in Krasnodar Krai at least four aims of educational policy must be achieved throughout the territory:

- the national standard of compulsory general education must be established, works and should be reached not formally statistically, but really , as full and active understanding of the curriculum of the educational institution;

- the document on education issued in Krasnodar Krai serves as the official document giving the right for continuation of education or job placement in all other territories (in conditions of Russia entering into the global educational space the document on education must be considered abroad); 
- the common standard of content and quality of education at its various levels is established and really ensured;

- the necessary conditions for continuation of education by persons of all ages are created.

It is to be also said about a scientific component, it's impossible without to copy with tasks of the educational process continuity effectively. $65 \%$ of all researches carried out in the interests of Krasnodar Krai fall to the share of the state and non-state universities, their scientific units-centers, technological parks, small scientific and innovative enterprises. In the territory of Krasnodar Krai the intellectual potential of the higher school is treated carefully. The administration actively uses the institutions as the state resource of transformations and the region development (Business Kuban, 2010).

\section{Methodological Aspects of Studying}

The scientific activity in the territory of Krasnodar Krai belongs to highly remunerative areas and brings considerable economic income. The state universities and the specialized research institutes present the basic part of the scientific educational park of Kuban.

The scientists of Krasnodar Krai carry out fundamental and applied researches on biology and medicine, chemistry and physics, mathematics, social and liberal sciences. The main directions of the scientific activity in Krasnodar Krai (State bodies Krasnodar, 2015):

- technologies of living systems;

- information and telecommunication technologies;

- $\quad$ new materials with the target features;

- optical and optoelectronic technologies;

- environmental monitoring and technologies of the environment rehabilitation, efficient environmental management;

- power engineering and alternative energy sources;

- new methods of diagnostics, diseases prevention and treatment of the person;

- agricultural processing technologies and functional foodstuffs;

- modern geodynamics, geophysics, seismicity of the region.

The basic researches are supported by the state, the public-private partnerships (PPP) is the basis for applied researches (State bodies Krasnodar, 2015). However the guestion we have to ask ourselves is how developed are PPP being the basis of applied researches in Krasnodar Krai? The Krasnodar Krai Department of strategic development, investments and external economic activity is the centre of the PPP.

According to this Department the public-private partnership in Krasnodar Krai is regulated by the following normative documents (2015):

- The federal law №115-FZ of 21 July 2005 "On the concession agreements" (as amended on 8 November, 4 December 2007, 30 June 2008, 17 July 2009, 2 July 2010);

- The Krasnodar Krai law №1989-KZ of 9 June 2010 "On the Krasnodar Krai state policy in the sphere of publicprivate partnership";

- The decree №97 issued by the head of the Krasnodar Krai administration (the governor) on 27 February 2010 "On the regional commission on the public-private partnerships of Krasnodar Krai" (as amended on 24 September 2010).

According to the federal portal "The PPP info. The infrastructure and the public-private partnership in Russia" there are three PPP working projects in Krasnodar Krai (2010):

- The rehabilitation and the development of water- supply and water disposal systems of the Krasnodar Krai's Azov-Black Sea coast;

- The investment program LLC «Krasnodar Vodokanal»;

- The construction of the sludge sediment co-incineration factory in the Adlersky City District of Sochi.

But there is also another project - the construction of the all-the-year-round resort "Gornaya Karusel" in Sochi which includes the objects of the Olympic Games-2014 infrastructure (Agafonov A. Yu., 2011) ".

It's to be noted that "the list of infrastructure projects which can be realized with the use of PPP mechanisms is created. About a half of them belong to Housing and Utilities infrastructure. Some examples from the other area: the construction of housing estates, objects of education, including preschool institutions. These projects are aimed at the solution of the housing problem", at the shortening of "queues" in kindergartens, at the increasing the preschool 
education level. Now the Krasnodar Krai administration and the municipal authorities conduct the work on preparation of the documentation and the search of the investor" (Agafonov A. Yu., 2011).

Evidently, the legislative base in the sphere of PPP is quite new, there is a few working projects which basically belong to Housing and Utilities infrastructure giving the author a chance to determine that the PPP in Krasnodar Krai is "rudimentary". It is also confirmed by the fact that Krasnodar Krai had been omitted from the list of the Russian Federation subjects with which in 2010-2012 the agreements on interaction and cooperation with The Public - private partnership development centre were signed (Moscow) (2013).

Despite that the Krasnodar Krai administration cooperates closely with The Public - private partnership development centre "... The executive authorities and the local government bodies hold together the meetings and conferences where the mechanisms and schemes of the PPP projects realization are discussed". (Agafonov A. Yu., 2011).

It is also said that "the cooperation on the question of the projects consideration relating to the possibility of their financing with the resources of CC «Vnesheconombank Group» has been established (Agafonov A. Yu., 2011).

The author marks that the questions of the development of the university science on the PPP basis aren't solved in practice although they are mentioned, for example, in FSBEI "The Kuban State University" "The Kuban State Universitythe systematic integrated scientific and educational centre of the southern macroregion" founded in 2011 where one of the main aims of the university is " the integration of innovative educational process and research activity, the development of the public-private partnerships forms providing the socioeconomic progress" (FSBEI HE "The Kuban State University", 2011).

Let's turn to postgraduate education that during the last two decades has been undergone the serious changes. Against the backdrop of falling in prestige of research and teaching activity in society the demand for academic degrees and qualifications by peoples who aren't engaged in such kind of activity has increased. It caused the expansion of postgraduate education serviceability, the quality decrease of diplomas, the disproportions in training the specialists of different professions and so forth. In the result there is less postgraduate education functioning relating to rehabilitation of the researches and teachers. Moreover, today postgraduate education failed to meet the requirements of the innovative country restructuring because it is almost does not focus on strategic priorities in the sphere of the science, equipment and technologies (Zubova L.G. and others, 2008).

Let's consider the reasons which, according to the author's opinion, can explain the problems mentioned above.

First, the demand increase for academic degrees and qualifications by businessmen, top managers, bank workers and other persons who aren't included in the scientific community structure is explained by:

- $\quad$ the desire "to add weight" and authority to yourself (the degree presence means that the citizen has prepared and defended the corresponding thesis work and by that he has proved the ability to think structurally);

- the financial side of the question (salaries' improvement, more chances for receiving the prestigious work or making expensive contracts with partners, especially with foreign partners);

- the progress on an action. When the main aims are achieved and there is no desire to stop, people start to improve their knowledge and results;

- the hopelessness: the desire to have those positions that demand the academic degree;

- the increasing dissociation of scientific and educational processes in the sphere of HE (the main part of protected belongs to it) that leads to derogation of the science value and "simplification" of the master's thesis works creation;

- because it's possible: the competitors have enough financial means to order the "turnkey". thesis work. Because of the low compensation level the teaching and scientific staff also uses the human capital for getting the additional profit.

The following fact is interesting: now the majority of managers has the candidate's degree, the doctor's degree is regarded as a bias in science more than in practice and realization of ideas, "to buy" the doctor's degree is much more difficult that causes unwillingness to get involved with it. As the result, according to statistics, for example, by the end of 2011 the post - graduate students ratio to the doctoral candidates was 3162 to 62 respectively.

On the basis of the definition, the higher educational institution is the educational institution which gives higher education and carries out the scientific activity (Wikipedia, 2015). The direct purposes of science are the description, the explanation and the processes and phenomena of the reality prediction (Wikipedia, 2015). That is what the student must to learn in the course of modern higher education and to what the education reforms must be directed.

The special attention is paid to this in the draft federal law "On education in the Russian Federation" coming into force since 1 January 2013 "... the support of experimental and innovative activity in the higher educational institutions and the development of additional education system. To teach the youth to get knowledge, and then to put them into 
practice, it is necessary to make a chain which will connect schools, secondary schools, colleges with the higher education institutions and the enterprises ..." (MEaS RF, 2012).

In Russia since 2008 the conception the national research university (NRU) is also introduced. That means the higher educational institution which is equally carrying out effectively educational and scientific activity on the basis of the principles of science and education integration (Wikipedia, 2015).

The start was given to the project of national research universities on 7 October 2008 by the decree of the Russian President "On the pilot project realization relating to creation of national research universities". In this decree two universities was given the status out of competition: MEPHI (The National Research Nuclear University) and MISIS (The National University of Science and Technology).

Further in 200912 higher education institutions taking part in open competition among the universities of the Russian Federation were given the status of NIU, in 201015 higher education institutions. In 2011 and 2012 there was no such practice.

Among the universities which sent the applications for competition in 2009 there were such leaders of the Krasnodar Krai higher school as "The Kuban State Technological University", "The Kuban State University", "The Kuban State Agrarian University". In 2010 "The Kuban State Technological University" didn't send the application.

Among the finalists of the first (2009) and the second (2010) competitive selection of the universities development programs in relation to which the status " the national research university" is established was only the Kuban State Agrarian University, but it was not among the number of winners.

The choice of the universities development programs that take part in competition was made on the basis of the analysis of the modern state and the dynamics of the universities development over the last 3 years following such criteria as staff potential, the educational process and scientific researches infrastructure, the educational and scientific innovative activity efficiency (the Government of the Russian Federation, 2009).

The author marks that no higher education institution of Krasnodar Krai was given the specified status. From this fact it's possible to make a conclusion that even the state higher educational institutions have the insufficient level of scientific and educational processes integration (being one of the main selection criteria).

The Minister of Education and Science of the Russian Federation Andrey Fursenko at a board meeting of the Ministry on 24 May 2011 points at the fact that "Today the declared in development programs figures are not achieved by a number of NIU " (MEaS RF, 2011). That allows to speak about a number of problems of this project realization.

During the spring control programs accomplishment concerning the development of NIU with emphasis on the first 14 universities that had much more time to achieve any visible results, it turned out, that NIU reports materials were prepared in such a way that according to them it is difficult to determine the qualitative results of the work on development programs. The majority of NIU operates their previous groundworks and know-how. The external reasons and the internal situation at universities resulted in that fact. The serious external reasons are the features and terms of the budget means appropriation for the development programs. In 2009 means were delayed and provided only by the end of the year. In 2010 there was a new problem: if in 2009 the financing was being carried out on the basis of estimates, in 2010 - in the context of the Federal target-oriented program on the "Research and Scientific- Pedagogical of Innovative Russia in 2009-2013" under "the others" that caused additional costs of the universities on the taxes payment (Dezhina I., 2012).

Nevertheless, even over a relatively short operating period on development programs at universities the successful practices started to appear. So, for example, the foundation of the post-graduate all-day centre in NIU HSE, the recruiting of teachers at the international labor market, the formation of scientific laboratories together with the foreign centers, additional payments for the scientific work and publications abroad are potentially effective measures.

It is important to estimate the happened changes from the point of view of the intensification of the academic staff inclusiveness to the scientific work because the conception of the research university itself means the active science development. In a number of the research universities this figure is above the average in the country: so, for example, in the St. Petersburg State Mining Institute of G. V. Plekhanov about $70 \%$ of the academic staff takes part in scientific work; whereas at the Russian higher education institutions the average is less than $20 \%$.

It is also to be noted that each NIU defined the figures threshold on its own. In some cases they were understated and therefore it was easy to achieve them. The government and NIU do not have the systematic understanding of the aims and ways of the elite universities development that is why there is a great number of "the uncertainty zones". It negatively influences on the ongoing work of the universities and their opportunities to make the long-term activity plans.

The achievement of the aims and the solution of tasks of the Federal target-oriented program on the "Research and Scientific - Pedagogical of Innovative Russia in 2009-2013" are carried out taking into consideration such provisions as " the increase of the students', post - graduate students' and young scientists' desire for the scientific activity", "the realization of the actions stimulating an expansion of interactions between subjects of the scientific and educational 
activity and also between sectors of science, education and high technologies, the active use of mechanisms of integration of science and education" (the Government of the Russian Federation, 2008).

If to pay attention to the mentioned above we can make a conclusion that integration of the scientific and educational processes is the most wanted in the HE sphere.

Historically in Russia the science and education are institutionally divided, but there are not yet effective legal base and adequate economic mechanisms of their integration (Kuznetsova A.S., 2009).

For our state the idea of integration of science and education is quite new. It was formulated about three centuries ago when the Academy of Sciences has been founded in Russia and that at that time already was aimed to carry out both scientific and educational activities.

Specifics of the institutional structure of science were confirmed during the Soviet era when along with a wide network of the academic and sectoral research institutes the departmental system of science management was formed. Within these conditions the integration of science and education had the fragmentary character and was under the concrete economic and military-political tasks solution [18].

In the early 1990s Russia has turned to a market way of economics development and that is why science and education were in a critical situation (Kuznetsova T.E., 2008).

It was caused by the fact that the local models of science and education have held out against the radical market reforms of the 1990s and also socioeconomic, legal and administrative innovations of the last years, in a number of circumstances.

The history will help to understand these circumstances:

- the first half of the XIX century: the university charters (1804 and 1835) "have not founded the necessary incentives to the scientific activity... The science activity at the universities especially depended on teachers' own willingness. In such conditions the enthusiasts only were interested in it. The scientific work development... has not proceeded because of the lack of the special scientific units at universities. The laboratories...that were here... were ill-equipped and first of all have usually focused on making the educational process possible, but not on the research work" (Strekopytov S. P., 2002);

- the second half of the XIX century: "The universities of the 1850s have stopped being scientific, "the utilitarian aspirations" have begun to prevail over the fundamental science interests. This situation has led to that fact that universities have just become the schools occupying, however, the highest step in the schools hierarchy. They became "the centres of ready knowledge" professors of which had just to give lectures, the scientific classes were not obligatory for them" (Dmitry B., 2003);

- the beginning of the XX century: "The scientific work for many gifted young scientists... has become the scientific asceticism. Therefore both university rooms and laboratories were considerably empty, and they were withering in the scientific work... (1903)".

In the first years of the Post-Soviet period the state tried to solve the common science and education problems by the differentiated methods, but this way, as is known, has not promote improvement for the situation in these spheres. The idea of science and education integration has again revived in the documents regulating the scientific activity. By the decrees of the Russian President on 13 June 1996 "№ 884 "On the doctrine of the Russian science development " and №903 "On the state support of integration of the higher education and fundamental science" the integration of science and education was officially declared as one of the major methods providing their preservation and development, and also as the principle of the state scientific and technical politics (Gordeeva A.N. and Bor).

The legal regulation of science and education integration in Russia was also presented by the points of the following federal laws:

- The law of the Russian Federation №3266-1"On education" from 10.07.1992;

- $\quad$ The federal law №125-FZ "On the higher and postgraduate professional education" from 22.08. 1996;

- $\quad$ The federal law №127-FZ "On science and the state scientific and technical policy" from 23.08.1996.

The last law (№ 127-FZ from 23.08.1996) the practice of which is less than 20 years has consolidated the principle of science and education integration at the legislative level.

The mentioned acts have become a legal impulse for a number of directive documents acceptance concerning science and education integration and have defined the legal prerequisites for creation of the regulatory and legal base governing the public relations in this field.

Because of the imperative need of development and state support of integration processes in the sphere of science and education the federal law №308-FZ "On modification of separate acts of the Russian Federation concerning science and education integration" from 1 December 2007 was accepted.

It is to be agreed that the main idea of the Bill is "the creation of legal conditions of science and education 
integration in Russia. The removal of administrative barriers and historically developed institutional division of these kinds of activity will allow using scientific and educational materials more effectively, economic and intellectual science and education resources. The main figure of integration efficiency in education and sciences is the education quality improvement... the main result of integration in science and education is development and enrichment of science and education" (2011).

Speaking about this law, it is to be mentioned that when the Federal Law on education from 29 December 2012 has taken effect it was revoked. According to this short period it is possible to make a conclusion that "the spreading" of the new law has not managed "to reach" the real solution of high school science problems both of the state and non-state universities.

So, though the science and higher education in our country in real life had been always developing not separately from each other, at the state level they were formally divided. The division of these intellectual activity types has three aspects (Gordeeva A.N. and Bor).

1) the institutional - science and education are considered by the legislation of the Russian Federation as an independent kind of activity;

2) the organizational and structural - science and education, including the highest professional, are independent spheres of the state administration, each of which has its own system of establishments, organizations and state bodies (except for the federal level where these spheres are now integrated represented by the Ministry of science and education of the Russian Federation);

3) the legal - each sphere is regulated by the independent branch of the legislation.

The possible way of overcoming of these problems and the direction of Russian education reforming is the integration of scientific and educational resources.

The author focuses attention that integration of the mentioned resources must be happened within two proceeding processes: educational and scientific going in parallel way. And this integration has to be proceeded in each higher educational institution as in the developed state universities, and at small non-state institutes, otherwise all federal target - oriented programs, laws and other legislative ensuring which have been forming in Russia in recent years within the country entrance into the global economic space, will just formally settle the existing problem of scientific and educational processes interaction at the higher school. The higher school of Krasnodar Krai will be faced with this problem because of the prevalence among types such type of educational institution institute.

It is possible to see the education quality and also the result of students research activity through the distribution of occupied in Krasnodar Krai economics on education level on fig. 1 (The Ministry of Economics of Krasnodar Krai, 2015).

According to the figure 1 the author makes a conclusion that the majority of workers is the population with general education (26,6\%), then with secondary professional education $(25,2 \%)$, but only then with higher $(24,6 \%)$. This fact is true in spite of demands by the majority of the enterprises and organizations of having higher education, and the high unemployment level. It can be explained by entrants' disinterest to continue training, misunderstanding of higher education value, falling of its prestigiousness.
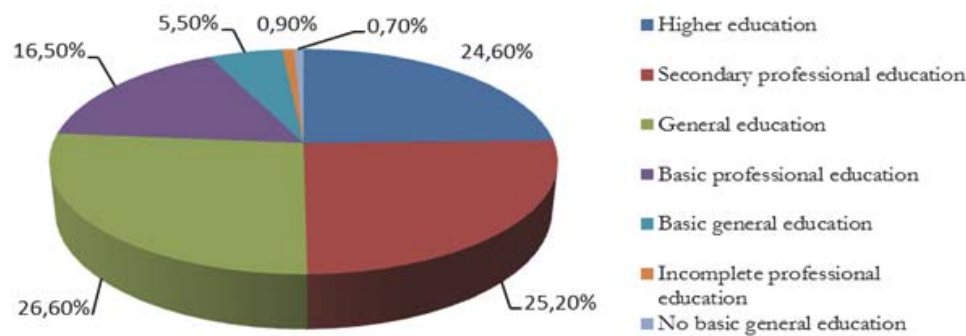

Figure 1 - The assignment of the working population in Krasnodar Krai economics on the education level in 2015

The integration of activity of the studied processes will increase the level young scientist and experts interest to the research process, thanks that they will be able to test their own received during the educational process knowledge, new skills and abilities on experience, and the introduction to the process the new labour and scientific force will also help to carry out the research activity more successfully. For the educational space, integration will allow to use fast new scientific achievements and discoveries during the educational process. So, the interaction of educational and research 
processes during their integration into the common scientific and educational area will influences upon both processes in positive way (Guseva A.I. and others, 2009).

It is to be noted that integration of scientific and educational areas became possible at observance of some factors, such as (Kozhin I.M., 2010):

- the common for both areas program and technical material base (the same laboratories, computer classes are often involved in both processes, there is the common access to the university library possessing scientific, methodical and educational literature);

- the participation of human and intellectual resources in the both areas activity (teachers, graduate students, doctoral candidates and even students can actively take part both in the educational and research processes and also to use received knowledge, abilities, experience - i.e. the intellectual resources);

- the presence of the common managing factors for both areas (i.e. the general administrative acts managing the processes going in both areas - the Legislation of the Russian Federation, the Charter of an Institution; and the presence of the common human resources managing the activity - administrators);

- the opportunity to use the intermediate and final results of the research activity in the educational process (various discoveries, new scientific methods, and also various material artifacts presented in the form of educational and methodical literature, and also programme objects created during the research activity may be the final and intermediate results).

We will agree with A. Guseva's opinion, the professor of the national research nuclear university "MEPHI", who considers in her researches within the FTP "Scientific and educational staff of innovative Russia (2009-2013)" scientific and educational areas integration on the following items (Guseva A.I. and others, 2009):

- the educational interaction - the direct teaching work such as giving seminars, lectures, participation in scientific conferences, laboratory researches, educational and research works, testing, and other types of educational and teaching work;

- educational elements are necessary elements of the educational activity, such as reports, course papers, presentations, educational and research works;

- the material and technological base is the thing that helps to organize teaching and scientific work. It is presented by the laboratories, computer classes, scientific equipment, library, electronic library, electronic courses or program trainers on courses.

If to consider "the educational interaction" and "the material base" positions on Krasnodar Krai, they will be characterized by figures of the educational and methodical work in HE institutions because especially these materials that are made by teaching staff there help to organize staff training. We will determine the substantial part through a number of printed pages of these materials (Table 1).

Table 1. The figures of educational and methodical work of the higher education institutions of Krasnodar Krai in 20112013

\begin{tabular}{|l|c|c|c|c|c|c|}
\hline \multirow{2}{*}{$\begin{array}{l}\text { The name of the higher education institutions } \\
\text { group }\end{array}$} & \multicolumn{2}{|c|}{$\begin{array}{c}\text { The total amount of } \\
\text { publications in 2011 }\end{array}$} & \multicolumn{2}{c|}{$\begin{array}{c}\text { The total amount of } \\
\text { publications in 2012 }\end{array}$} & \multicolumn{2}{c|}{$\begin{array}{c}\text { The total amount of } \\
\text { publications in } 2013\end{array}$} \\
\cline { 2 - 8 } & total & on the staff & total & on the staff & total & on the staff \\
\hline The state universities and their branches & 10685 & 10219 & 13901 & 13095 & 84543 & 83924 \\
\hline The non- state universities and their branches & 4507 & 3609 & 3407 & 2758 & 3050 & 2358 \\
\hline $\begin{array}{l}\text { The branches foreign-regional higher } \\
\text { educational institutions }\end{array}$ & 3121 & 2892 & 3620 & 2782 & 4692 & 3410 \\
\hline The total number & 18313 & 16720 & 20928 & 18635 & 92285 & 89692 \\
\hline
\end{tabular}

The analysis of Tab. 1 shows that the state universities in the conditions of the education system reforming have "responded" to a call of the economics that is forming and based on knowledge in the region, the abrupt level of printed pages in 2013 from previous years more than 6 times higher shows that. The conclusion is that the substantial prevails over the quantitative.

The opposite situation is with the non-state higher education institutions. According to the figures they don't fill the substantial part and on the contrary there is an annual reduction from 4507 in 2011 to 3050 in 2013.

"The educational interaction" and "educational elements" positions on Krasnodar Krai will be characterized by the figures of the students' research work the HE sphere (Table 2) and the figure of the average of students to one teacher (Table 3). 
From Tables 2 and 3 it is possible to make the following conclusion:

- the figure of the open competitions number on the best scientific work of students that are held in the non-state higher education institutions by the order of the Ministry of Education and Science practically didn't change over the last three years;

- the number of competitions on the best SRW of the students organized by both the state and the non-state higher education institutions also wasn't undergone strong changes;

- the number of the students of full-time tuition participating in SRW in the non-state sector is considerable decreased on 1,4 times from 6136 to 4467 people;

- $\quad$ by the number of scientific publications of students in 2013 as in 2011 the public sector prevails, but by the number of the grants that were won by students the public sector sharply failed (from 215 in 2011 to 87 in 2013), the non-state higher education institutions practically go in parallel with the state.

Table 2. The cumulative information on the level of the research work organization of students in Krasnodar Krai in 2008 and 2013

\begin{tabular}{|c|c|c|c|c|c|c|c|c|c|c|}
\hline \multirow[t]{2}{*}{$\begin{array}{l}\text { The name of the } \\
\text { higher education } \\
\text { institutions group }\end{array}$} & \multicolumn{2}{|c|}{$\begin{array}{l}\text { The open competitions on the best } \\
\text { scientific work of students held by the } \\
\text { higher education institution by the order } \\
\text { of the Ministry of Education and Science }\end{array}$} & \multicolumn{2}{|c|}{$\begin{array}{l}\text { Competitions on the } \\
\text { best SRW of the } \\
\text { students organized by } \\
\text { the higher education } \\
\text { institution }\end{array}$} & \multicolumn{2}{|c|}{$\begin{array}{l}\text { The Number of the } \\
\text { students of full-time } \\
\text { tuition participating in } \\
\text { SRW }\end{array}$} & \multicolumn{2}{|c|}{$\begin{array}{l}\text { The number of } \\
\text { scientific } \\
\text { publications }\end{array}$} & \multicolumn{2}{|c|}{$\begin{array}{l}\text { The grants } \\
\text { that are won } \\
\text { by students }\end{array}$} \\
\hline & 2011 & 2013 & 2011 & 2013 & 2011 & 2013 & 2011 & 2013 & 2011 & 2013 \\
\hline $\begin{array}{l}\text { The state } \\
\text { universities and } \\
\text { their branches }\end{array}$ & 32 & 77 & 112 & 118 & 24944 & 24351 & 2881 & 3670 & 215 & 87 \\
\hline $\begin{array}{l}\text { The non- state } \\
\text { universities and } \\
\text { their branches }\end{array}$ & 21 & 27 & 137 & 145 & 6136 & 4467 & 1578 & 1790 & 26 & 67 \\
\hline $\begin{array}{l}\text { The branches } \\
\text { foreign-regional } \\
\text { higher educational } \\
\text { institutions }\end{array}$ & 28 & 30 & 118 & 132 & 4153 & 3260 & 1134 & 1052 & 5 & 4 \\
\hline The total number & 81 & 134 & 367 & 395 & 35233 & 32078 & 5593 & 6512 & 246 & 158 \\
\hline
\end{tabular}

Table 3. The figure of the average of students to one teacher according the types of the educational institutions (the beginning of an academic year; a person)

\begin{tabular}{|l|c|c|c|c|c|}
\hline The figures/an academic year & $2010 / 11$ & $2011 / 12$ & $2012 / 13$ & $2013 / 14$ & $20114 / 15$ \\
\hline $\begin{array}{l}\text { The figure of the average of students to one teacher in the state and } \\
\text { municipal higher educational institutions }\end{array}$ & 19 & 19 & 19 & 20 & 20 \\
\hline $\begin{array}{l}\text { The figure of the average of students to one teacher in the non-state } \\
\text { higher educational institutions }\end{array}$ & 15 & 17 & 16 & 16 & 22 \\
\hline
\end{tabular}

Let's pay our attention to the "the number of the students of full-time tuition participating in SRW" because if this figure will not undergo some changes that can lead to its decrease the situation for the education development of the region will be critical.

It is necessary to say that the explanation of such tendency is first connected with the increase of the average number of students to one teacher in the non-state higher educational institutions, as it is shown in Tab. 14 (from 15 in 2010/11 academic years to 22 in 2014/15 academic years).

We will explain. The students who only start science, in the higher education institution look for it in their own realization, it is possible only under the good control of the professor. At this stage it is important to involve the students in the scientific process as much as possible and to show how it is possible to use it effectively in the interaction with the educational process. For this purpose it is important to strength an education individualization on order each student feels himself unique, wanted, useful and do not dive up the scientific work.

How does it possible in case when the number of students to one teacher increases? Then the professor will just have no time to work with each student, the connection will lost and the student will think that the scientific process is not the necessary part of the educational process, but obligatory. The practice shows that the obligatory thing is not always interesting learning it often leads to the minimum results without the development further. 
Despite it, a concrete hint is made in the Concept of the Federal target- oriented program of the education development from 2016 to 2020 (the Government of Russia, 2014) concerning the reduction of pedagogical workers " ... because of the considerable number of the released workers of higher education there is a need to create mechanisms of the social adaptation and professional retraining of the mentioned category of workers for their timely orientation at the modern labor market ...".

The ratio of students of full-time tuition total number to a number of the students participating in SRW in 2013 is in the non-state higher education institutions 7,9 thousand people to 4,5 thousand people. That means that $57 \%$ of students are engaged in scientific activity but the good result must be $100 \%$ because the elements of the scientific process have always to be present in the educational (independent work, writing of papers, courses and diplomas).

\section{Conclusion}

The author thinks that in the knowledge model according to which the higher education institutions worked on old SES, the educational process is priority - the student had to "know" that means that the teaching stuff had to give knowledge to students. The competence-based approach on new FSES considers knowledge only as the tool for mastering one or another basic ability, the student has not only to "know", but also "to own" knowledge. In the latter case the priority is given to educational and scientific processes interaction. The integration of the specified processes as a set of the coordinated conditions, provides:

- the increase of a level of education quality;

- the focused personal approach;

- close links in training and scientific development of the student;

- $\quad$ the optimization of the activity organization of the teacher and student;

- the education individualization;

- the humanization of the educational process, the assuming joint creative, the scientific activity of the teacher and student.

Therefore, the number of students to one teacher must decrease in order it will be possible to keep the specified conditions. It allows to make a conclusion that the scientific process plays a supporting role in the majority of the higher education institutions of Krasnodar Krai.

It is to be noted once again that at the modern stage of education reforming the main aims in the field of science and education integration are the preservation and preparation of scientific stuff, the use of scientific and experimental base in the educational process, in carrying scientific researches in units of the higher school (Kozyrina A.N., 2008)

Thus, the main aim at the modern stage of education reforming must be a disclosure of potential of the scientific and educational processes interaction in the service organizations in the higher education sphere and justification of tools of these processes integration.

\section{References}

Wikipedia. The free encyclopedia http://ru.wikipedia.org/wiki/Vysshee_uchebnoe_zavedenie _ Gadzhieva E.Yu. Razvitie partnorskogo vzaimodeystviya gosudarstvennyh i chastnyh organizatsiy v protsesse modernizatsii sfery obrazovatel'nyh uslug(na materialah Krasnodarskogo kraya). Dis.na soisk.uch.st.kand.ekon.nauk.Maykop.-2013

Gordeeva A.N., Puchkova M.V. Pravovoe obespechenie integrtscii nauki i obrazovaniya. The law.2006 №4 Gosudarstvenno-chastnoe partnerstvo.

Normativnaya baza. Ministerstvo strategicheskogo razvitiya, investitsiy i vneshneekonomicheskoy deyatel'nosti Krasnodarskogo kraya http://www.investkuban.ru/gchp_nb.html

Guseva A.I., Kireev V.S., Tihomirova A.N., Filippov S.A., Tsyplakov A.S.

Informatsionno-obrazovatel'nyy portal MIFIST issledovatel'skogo jadernogo universiteta. Programmnye produkty i sistemy, № 3, 2009.

Guseva A.I., Kozhin I.M., Ivanov A.V. Razrabotka modeli integratsii nauchnogo i obrazovatel'nogo prostranstv. Mezhdunarodnaya telekommunikatsionnaya konferentsiya studentov i molodyh uchenyh. «Molodezh' i nauka» http://www.mephi.ru/molod/molod_ 2009/docs.php?SECTION_ID=1339

Dezhina I. Programmy razvitiya natsional'nyh issledovatel'skih universitetov: itogi pervyh dvuh let.

INFONAUK.RU Nauchno-obrazovatel'nyy daydzhest http://infonauk.ru/post_1307702304.html

Delovaya Kuban'. Obrazovanie i nauka http://www.business-kuban.ru/naukā-i-obrazovanie

Doklad obschestvennoy palaty RF «Obrazovanie i obschestvo: gotova li Rossiya investirovat' v svoe budushchee?». Obschestvennaya palata Rossyskoy Federatsii.-Moscow, 2007

Zelinskaya M.V. Integrirovannye informativnye instrumenty razvitiya regional'noj ekonomicheskoy sistemy. Krasnodar: JulM, 2010.

Zubova L.G., Andreeva O.N., Antropova O.A., Arzhanyh E.V. Rossyskoe poslevuzovskoe obrazovanie: problemy i puti ih resheniya. 
Federal'noe gosudarstvennoe byudzhetnoe nauchnoe uchrezhdenie «Centr issledovany i statistiki nauki» http://www.csrs.ru/ inform/IAB/bulleten_2008_2.pdf

Konferentsiya «Informatsionnye tehnologii v obrazovanii» «ITO-Moscow-2010» http://msk.ito.edu.ru/2010/section/64/2291/index.html

Kommentariy k Federal'nomu zakonu «O vysshem i poslevuzovskom professional'nom obrazovaniil». Pod red. A.N. Kozyrina. M.: Norma, 2008.

Kuznetsova A.S. Integratsiya nauchnyh i obrazovatel'nyh resursov kak napravlenie obrazovatel'noy reformy. Advokat, 2009.

Kuznetsova T.E. Doklad «Perspektivy integratsionnyh protsessov v sfere nauki i obrazovaniya» na Doklad na IX mezhdunarodnoy konferentsii «Modernizatsiya ekonomiki i globalizatsiya» 3-5 April 2008. Moscow.

Material iz Wikipedia. Prikladnye issledovaniya http://ru.wikipedia.orgh

Mezhlumova V.R. Nauchnaya sostavlyayuschaya v sfere vysshego professional'nogo obrazovaniya Krasnodarskogo kraya. Ekonomika ustoychivogo razvitiya. 2012. № 12.

Mezhlumova V.R. Ekonomicheskie aspekty razvitiya sfery vysshego professional'nogo obrazovaniya Krasnodarskogo kraya. Novye tehnologii. 2011. №3.

Ministerstvo ekonomiki Krasnodarskogo kraya. Krasnodarskiy kray - territoriya bol'shih vozmozhnostey. Prezentatsiya http://economy. krasnodar.rul

Nauka i krizisy. Istoriko-sravnitel'nye ocherki. SPb.: Dmitriy Bulanin, 2003.

Novikov V.S. Gosudarstvennoe-chastnoe partnerstwo kak mechanism transformatsii sferi obrazovatelnich uslug. Russian Federation. Monographija. Krasnodar 2010.

Krasnodar: RIO JulM. - 2010.

O Kontseptsii Federal'noy celevoy programmy razvitiya obrazovaniya na 2016 - 2020.

Rasporyazhenie Pravitel'stva Rossii from 29 December 2014 № 2765-R. Spravochno-pravovaya sistema «Pravo.ru». http://docs.pravo. ru/document/view/64036519/7484 3648/

Obrazovanie v Krasnodarskom krae 2007-2011. - K.: Statisticheskiy sbornik 2012.

Obrazovanie v Krasnodarskom krae 2009-2013. - K.: Statisticheskiy sbornik 2014.

Podvedeny itogi razvitiya natsional'nyh issledovatel'skih universitetov v 2009-2010. Ministerstvo obrazovaniya i nauki Rossyskoy Federatsii http://minobrnauki.rf/press-centr/801

Portal ispolnitel'nyh organov gosudarstvennoy vlasti Krasnodarskogo kraya. Nauka v Krasnodarskom krae http://www.krasnodar.ru/ content/521/show/5596/

Postanovlenie Pravitel'stva Rossyskoy Federatsii from 13 July 2009 N 550 «O konkursnom otbore programm razvitiya universitetov, v otnoshenii kotoryh ustanavlivaetsya kategoriya «natsional'nyy issledovatel'skiy universitet». Ministerstvo obrazo-vaniya i nauki Rossyskoy Federatsii http://old.mon.gov.ru/dok/prav/obr/5556/

Poyasnitel'naya zapiska k proektu federal'nogo zakona «O vnesenii izmeneniy v Zakon Rossyskoy Federatsii «Ob obrazovanii» i v federal'nye zakony «O vysshem i poslevuzovskom professional'nom obrazovanii», «O nauke i gosudarstvennoy nauchnotehnicheskoy politike».

Programma strategicheskogo razvitiya FGBOU VO «Kubanskiy gosudarstvennyy universitet» «Kubanskiy gosudarstvennyy universitet sistemny integrirovannyy nauchno-obrazovatel'nyy centr juzhnogo makroregiona» utverzhdena on 29 November 2011. http://www.kubsu.ru/documents/program.pdf

Programma uluchsheniya investitsionnogo klimata v Krasnodarskom krae na 2011 - 2015. Ministerstvo strategicheskogo razvitiya, investitsiy i vneshneekonomicheskoy deyatel'nosti Krasnodarskogo kraya. http://investkuban.ru/kk516.html

Stenogramma zasedaniya Prezidiuma Pravitel'stva Rossii on 26 July 2012. Ministerstvo obrazovaniya i nauki http://minobrnauki.rf/ novosti/2499

Strekopytov S. P. Istoriya nauchno-tehnicheskih uchrezhdeniy v Rossii (vtoraya polovina XIX-XX vv.). M.: RGGU, 2002.

Trudy vysochayshe uchrezhdennoy Komissii po preobrazovaniyu vysshih uchebnyh zavedeniy. SPb., 1903. Vyp. IV.

Federal'naya tselevaya programma «Nauchnye i nauchno-pedagogicheskie kadry innovatsionnoy Rossii» na 2009-2013. Utverzhdena postanovleniem Pravitel'stva Rossyskoy Federatsii from 28 July 2008 № 568 http://www.fcpk.ru/catalog.aspx?Catalogld=259

Federal'nyy zakon from 23 August 1996 N 127-FZ «O nauke i gosudarstvennoy nauchno-tehnicheskoy politike». Informatsionnopravovoy portal. http://base.garant.rul

Federal'nyy zakon from 29 December 2012 N 273-FZ «Ob obrazovanii v Rossyskoy Federatsii». Informatsionno - pravovoy portal. http:// base.garant.ru/

Federal'nyy portal «GChP info. Infrastruktura i gosudarstvenno-chastnoe partnerstvo v Rossii». Regiony http://www.pppi.ru/regions/

Tsentr razvitiya gosudarstvenno-chastnogo partnerstva. Regiony http://pppcenter.ru/ru/regions 